\title{
Knowledge, Attitudes and Behaviours Related to HIV/AIDS among Female Migrant Workers in the Restaurant Industry in Guangzhou, China
}

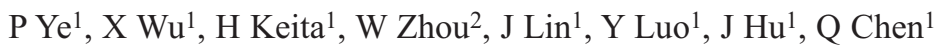

\begin{abstract}
Objective: The goal of the present study was to assess knowledge and attitudes related to HIV/AIDS among the migrant female workers in the restaurant industry in Guangzhou City, China.

Methods: We performed a questionnaire survey using a judgmental sampling method in the health examination clinic of Yuexiu District of Guangzhou during March 2011. A total of 428 participants completed and returned the questionnaires and data were analysed by descriptive statistics, $t$-test, one way ANOVA, and Wilcoxon test.

Results: Of 428 respondents, the average score of HIV/AIDS-related knowledge was 19.6 (full marks, 26). Knowledge on HIV/AIDS among respondents was classified as poor for $8.2 \%$, fair for $42.5 \%$, and good for 49.3\%. The average score of AIDS-related attitudes of respondents was 7.2 (full marks, 10). Most of the respondents $(88.8 \%)$ had relatively positive attitudes toward AIDS. Unmarried status, ages less than 30 years old and higher levels of education had higher scores of knowledge. Among the respondents who had sex experiences, 57.7\% (130/225) reported that they never or only some of the time used condom. The young, unmarried women had significantly higher proportion of condom use than those above 30 years old, and/or married ones.

Conclusions: Overall, a half of respondents had only moderate and low levels of awareness about HIV/AIDS knowledge, although most of them had tolerant and positive attitudes toward HIV/AIDS. In addition, a relatively lower rate of condom use was reported. The findings indicate that there exists broad space for improvement of knowledge and behaviours toward HIV/AIDS for migrant women in China.
\end{abstract}

Keywords: Attitude, behaviour, Guangzhou, knowledge, migrant female worker, restaurant industry

\section{Conocimientos, Actitudes y Comportamientos Relacionados con el VIH/SIDA entre las Trabajadoras Emigrantes en la Industria de Restaurantes en Guangzhou, China

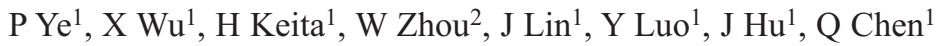

\begin{abstract}
RESUMEN
Objetivo: El objetivo del presente estudio fue evaluar los conocimientos y actitudes relacionadas con el VIH/SIDA entre las trabajadoras emigrantes en la industria de restaurantes en la ciudad de Guangzhou, China.

Métodos: Realizamos una encuesta en forma de cuestionario utilizando un método de muestreo a juicio en la clínica de examen de salud del distrito de Yuexiu de Guangzhou en marzo de 2011. Un total de 428 participantes llenaron y entregaron los cuestionarios, y los datos fueron analizados mediante estadisticas descriptivas, prueba t, ANOVA unidireccional, y prueba de Wilcoxon.

Resultados: De las 428 encuestadas, la puntuación media de los conocimientos relacionados con el VIH/SIDA fue 19.6 (puntuación máxima, 26). El conocimientos sobre el VIH/SIDA entre las encuestadas fue clasificado de pobre por el 8.2 por ciento, aceptable por el 42.5\%, y bueno por el 49.3\%. La puntuación promedio de las actitudes relacionadas con el SIDA entre las encuestadas fue
\end{abstract}

From: ${ }^{1}$ Department of Epidemiology, School of Public Health and Tropical Medicine, Southern Medical University, 1838 Guangzhou North Road, Guangzhou, 510515, Guangdong Province, China and ${ }^{2}$ Yuexiu District of Guangzhou Centre for Disease Control and Prevention, Zhongshan San Lu, Yuexiu District, Guangzhou, 510030, Guangdong Province, China.
Correspondence: Professor Q Chen, Department of Epidemiology, School of Public Health and Tropical Medicine, Southern Medical University, 1838 Guangzhou North Road, Guangzhou, China, 510515. E-mail: qch.2009@ 163.com 
7.2 (puntuación máxima, 10). La mayoría de las encuestadas (88.8\%) tenían actitudes relativamente positivas hacia el SIDA. El estado civil de soltero, las edades menores de 30 años, y los niveles de educación más altos, estuvieron asociados con puntuaciones más altas de conocimiento. Entre las encuestadas que tenían experiencias sexuales, el 57.7\% (130/225) reportó no haber usado condones nunca, o sólo algunas veces. Las mujeres jóvenes solteras hicieron un uso del condón en proporción significativamente mayor que las mujeres mayores de 30 años, y/o las casadas.

Conclusiones: En general, la mitad de las encuestadas tenía sólo niveles de conciencia moderados y bajos en cuanto a conocimientos de VIH/SIDA, aunque la mayoría de ellas tenía actitudes tolerantes y positivas hacia el VIH/SIDA. Además, se reportó una tasa relativamente baja de uso del condón. Los hallazgos indican que existe un amplio espacio para mejorar tanto los conocimientos como las conductas hacia el VIH/SIDA para las mujeres emigrantes en China.

Palabras claves: Actitud, comportamiento, conocimiento, trabajadora emigrante, Guangzhou, industria de restaurantes

West Indian Med J 2013; 62 (4): 330

\section{INTRODUCTION}

At the end of December 2010, the cumulative reported HIVinfected patients around the world, including those who had progressed to AIDS, stood at 34 million. An estimated 2.7 million were newly infected with HIV and 1.8 million lost their lives due to AIDS (1). To the world, HIV/AIDS remains a major challenge and one of the most serious public health and social problems.

Since China's first reported indigenous case of AIDS was identified in Ruili City, Yunnan province in 1989, HIV/ AIDS has spread numerically and geographically throughout the country. Today, HIV-positive populations are distributed in all 31 provinces and municipalities of China, of which around three-quarters live in five Chinese provinces: Yunnan, Henan, Xinjiang, Guangxi, and Guangdong (2). According to previous research, migrant workers, particular women, are not only at high risk for HIV infection, but also serve as potential "bridge populations" in the virus spreading nationwide, or even worldwide (3-5).

With rapid industrialization and urbanization, millions of Chinese peasants leave their home towns and villages and head to the cities for work. According to the statement of China's $6^{\text {th }}$ National Population Census, the internal migrants in 2010 , as compared to 2000 , increased by $81.03 \%$, with a total number of over 221 million (6). Migrant workers today account for about 20 per cent of Chinese working-age population (15 to 64 years old). A vast majority of the migrants are young, in the sexually active period of their lives, far from home and families, have lower educational level and are poorly paid (7). According to a research report, migrants accounted for $45.1 \%$ of HIV-positive people in Chongqing City, Sichuan Province in 2005 (2). Another study reported an estimation of $0.75 \%(95 \%$ CI: $0.42,1.08)$ for the prevalence of HIV among migrants in 2009 (5). Of particular note is the rise in HIV infection among migrant women (2-5). However, compared with other populations at high risk of HIV infection, such as intravenous drug users (IDUs), commercial sex-workers (CSWs) and men who have sex with men (MSM), the migrant workers attracted relatively less concerns, which therefore impelled us to pay more attention to the migrant populations in China.

In the past decade, the Chinese government has made great efforts in HIV/AIDS control and prevention among the high-risk populations, including education, condom promotion, methadone maintenance treatment (MMT) and free needle exchange for IDUs (7). However, HIV/AIDS in China continues to increase. In September 2001, the Chinese Ministry of Health reported a total of 28133 people with HIV infection (8). While by the end of August 2010, the cumulative total of reported HIV-positive was 361599 , including 127203 AIDS cases and 65104 recorded deaths (9). HIV infection is mostly attributed to risk behaviours such as unsafe sexual practices and intravenous drug use. The most commonly used intervention strategy for HIV infection is HIV/AIDS-related knowledge education and reduction of risk behaviours. The migrant female workers' lack of knowledge contributes to risk behaviours for HIV/AIDS than the permanent city residents, as they were in the lower class of the society.

Guangzhou is the capital of Guangdong province and is the third largest city in China and the largest city of southern China. As of the 2010 national census, the city had a population of 12.78 million, around which half are migrants. Because of a high proportion of HIV infection in the migrants in China, we speculated that the migrants, especially women, might have a low level of knowledge about HIV/AIDS. Some surveys on knowledge, attitude and behaviours related to HIV/AIDS among female migrant workers had already been carried out in some cities of China, most of which were about female workers in the manufacturing industry or female sex-workers (10-15). However, insufficient information is available to reveal HIV/AIDS-related knowledge, attitude and behaviours among migrant women working in the services industry. Herein, we conducted a survey to assess HIV/AIDS-related knowledge, attitude and behaviours among the female migrant workers in the restaurant industry in Guangzhou City. 


\section{SUBJECTS AND METHODS}

We performed a cross-sectional survey using a judgmental sampling method in the health examination clinic of Yuexiu District of Guangzhou Centre for Disease Control and Prevention during 2011. Yuexiu District is the centre of administration, business, finance and culture of Guangzhou City with the largest population density. Thus there is a large number of female migrant workers in this area, and most of whom worked in service industries, such as in restaurants.

The participant sample was obtained from the health examination clinic exclusively for migrant female workers annually in Guangzhou City. We selected all migrant females who worked in the restaurant industry and checked their physical health during March 2011. Migrant workers are defined as those who left their home towns to work in Guangzhou City for over six months (6). Migrants from 15 to 64 years of age were eligible for the study.

A self-administered questionnaire for assessing HIV/AIDS-related knowledge, attitude and behaviours was designed by Guangzhou Centres for Disease Control and Prevention. The questionnaire included participants' demographic and socio-economic characteristics, HIV/AIDS-related knowledge, attitude and behaviour. Knowledge of HIV/ AIDS was assessed by a 26-item questionnaire, which included general knowledge (7 items), transmission (15 items), and protection (4 items). A 10-item questionnaire was used to measure attitude toward HIV/AIDS, including attitude toward HIV/AIDS-related behaviours (4 items), persons with AIDS (4 items), and AIDS prevention (2 items). Another two questions were about sexual practices and condom use.

Approximately 25-30 minutes were needed to fill out the questionnaire. Participants completed a self-administered questionnaire in a separate room or private space at the workplace or a nearby place convenient to participants. The questionnaires were immediately collected when the participants finished the questions.

Knowledge and attitude was measured by the number of correct responses to 26 and 10 questions, respectively. One point was given for each correct answer and zero point for each incorrect or the unknown answer. Scores of knowledge were categorized into three levels: poor, fair and good. A score of 13 or below was considered as a poor level of knowledge, between 13 to 20 was considered as fair knowledge, and 21 or great was considered as good knowledge. Score of attitude was categorized into positive and negative. A score of five or less was considered as negative attitude and score between six and 10 was considered as positive attitude.

Data were double-entered and managed using Epidata 3.0 software (The EpiData Association, Odense Denmark, 2003) and were edited via computerized range and logic checks to flag any missing, inconsistent or out-of-range values during the entry. SPSS version 13.0 (SPSS Inc., Chicago, Il, USA) for the Windows software was used to perform the statistical analysis. Data were analysed using descriptive statistics, $t$-test, one way ANOVA, and Wilcoxon test. Multiple comparisons were performed by LSD test. $P$ value $<0.05$ was considered statistically significant.

This study was approved by the Guangzhou Municipal Health Bureau, and all participants were informed of the study's objectives and signed the informed consent form before participation. Anonymity and confidentiality were guaranteed to the subjects who participated voluntarily in the survey and they were given the option to skip any question and/or withdraw from the study at any point.

\section{RESULTS}

\section{Sociodemographic characteristics of the subjects}

A total of 428 migrant workers were enrolled in the survey. The mean age of the participants was 26.3 years (SD, 9.7 years; range, 15-56 years). The mean age of the married participants was 37.5 years (SD, 9.1 years), while unmarried ones were 21.5 years (SD, 4.7 years). Of 428 participants, $324(75.7 \%)$ were under 30 years old. The majority of participants $(65.7 \%)$ lived in Guangzhou less than four years. The details of the sociodemographic characteristics of the migrants are shown in Table 1.

Table 1: $\quad$ Sociodemographic characteristics of 428 female migrants

\begin{tabular}{ccc}
\hline Characteristic & Frequency (n) & Per cent (\%) \\
\hline Marital status & & \\
Married & 127 & 29.7 \\
Unmarried & 301 & 70.3 \\
Age & 324 & 75.7 \\
$<30$ years & 104 & 24.3 \\
$\geq 31$ years & 17 & \\
Educational level & 203 & 4.0 \\
Primary school & 164 & 47.4 \\
Junior high school & 44 & 38.3 \\
Senior high school & & 10.3 \\
College and above & 165 & 38.6 \\
Monthly income (Yuan) & 242 & 56.5 \\
$<1000$ & 21 & 4.9 \\
1000-3000 & & \\
$>3000$ & & \\
\hline
\end{tabular}

\section{Knowledge about HIV/AIDS}

Of 428 respondents, $91.6 \%$ reported that they had ever heard of HIV/AIDS, obtained from various sources. The main source was television (55.3\%), followed by magazine/ newspaper $(34.9 \%)$, book $(20.8 \%)$, radio broadcast $(16.6 \%)$, friends $(14.5 \%)$ and class training (12.4\%). Only $9.1 \%$ reported they obtained the knowledge from health-workers.

Of respondents, the average score of HIV/AIDSrelated knowledge was 19.6 (SD 4.1, range 2-26). The accuracy rate of each item ranged from $22.4-97.0 \%$. The highest accuracy rate was for the item "blood for transfusion use must be tested for the AIDS virus" (97.0\%). The lowest accuracy rate was for the item "the virus can be transmitted by mosquito bite" (22.4\%). Of 428 respondents, knowledge 
on HIV/AIDS was classified as poor for $8.2 \%$, fair for $42.5 \%$, and good for $49.3 \%$.

A total of $19.9 \%$ of participants believed that AIDS can be cured at present, and $27.3 \%$ of respondents did not know that AIDS was a sexually transmitted disease. A vast majority of the respondents (94.4\%) knew that AIDS could be transmitted through blood transfusion, followed by other high correct responses like sharing syringes (91.8\%), sex with AIDS patients (90.2\%), and sharing tattoo needles $(87.6 \%)$. On the contrary, significant misconceptions were as follows: one could be infected with HIV through mosquito bite $(69.2 \%)$, hugging or kissing with AIDS patients $(40.0 \%)$, close stool sharing (42.5\%) and swimming with AIDS patients $(21.0 \%)$. As for AIDS prevention, it was commonly considered (94.2\%) that AIDS was preventable. Nonetheless, about a quarter of the participants $(23.6 \%)$ was ignorant of the necessity of condom use. The answers of respondents on knowledge about HIV/AIDS are presented in Table 2.
There were significant associations between the knowledge scores and sociodemographic characteristics among the participants. Unmarried status, less than 30 years old, higher levels of education had higher scores, while monthly income was not associated with knowledge of HIV/AIDS (Table 3).

\section{Attitude toward HIV/AIDS}

Of respondents, the average score of AIDS-related attitudes was 7.2 (SD 1.3, range 0-10). The positive rate of each item ranged from 2.4-98.4\%. Most respondents (88.8\%) had relatively positive attitude toward AIDS. However, $80.1 \%$ of respondents answered that they would be fearful if they made contact with AIDS patients. Moreover, 97.4\% of participants considered that AIDS patients should be separated. On the other hand, more than $90 \%$ of respondents who had been aware of the necessity of AIDS prevention education expressed a great readiness to acquire knowledge about HIV/AIDS or other venereal diseases. The details of atti-

Table 2 Knowledge about HIV/AIDS among 428 participants

\begin{tabular}{|c|c|c|c|c|}
\hline Knowledge & $\begin{array}{l}\text { Yes } \\
(\%)\end{array}$ & $\begin{array}{l}\text { No } \\
(\%)\end{array}$ & $\begin{array}{l}\text { No idea } \\
(\%)\end{array}$ & $\begin{array}{l}\text { Accuracy } \\
\text { Rate (\%) }\end{array}$ \\
\hline \multicolumn{5}{|l|}{ Knowledge about AIDS } \\
\hline Is AIDS an infectious disease & $392(91.6)$ & $20(4.7)$ & $16(3.7)$ & 91.6 \\
\hline Is AIDS a sexually transmitted disease & $311(72.7)$ & $69(16.1)$ & $48(11.2)$ & 72.7 \\
\hline $\begin{array}{l}\text { Will the symptoms of AIDS appear } \\
\text { soon }\end{array}$ & $140(32.7)$ & $196(45.8)$ & $92(21.5)$ & 45.8 \\
\hline Can AIDS be cured at present & $85(19.9)$ & $263(61.4)$ & $80(18.7)$ & 61.4 \\
\hline Would he/she die immediately & $32(7.5)$ & $359(83.9)$ & $37(8.6)$ & 83.9 \\
\hline \multicolumn{5}{|l|}{$\begin{array}{l}\text { Which way listed below can } \\
\text { spread AIDS }\end{array}$} \\
\hline Blood transfusion & $404(94.4)$ & $12(2.8)$ & $12(2.8)$ & 94.4 \\
\hline Having sex & $386(90.2)$ & $29(6.8)$ & $13(3.0)$ & 90.2 \\
\hline Dining together & $81(18.9)$ & $322(75.2)$ & $25(5.8)$ & 75.2 \\
\hline Sharing close stool & $182(42.5)$ & $217(50.7)$ & $29(5.8)$ & 50.7 \\
\hline Swimming & $90(21.0)$ & $300(70.1)$ & $38(8.9)$ & 70.1 \\
\hline Working together & $66(15.4)$ & $336(78.5)$ & $29(6.1)$ & 78.5 \\
\hline Hugging or ritual kissing & $174(40.0)$ & $226(52.4)$ & $31(7.2)$ & 52.4 \\
\hline Sharing tattoo needle & $375(87.6)$ & $42(9.8)$ & $11(2.6)$ & 87.6 \\
\hline Sharing syringe & $393(91.8)$ & $22(5.1)$ & $13(3.0)$ & 91.8 \\
\hline Mother to her unborn children & $361(84.3)$ & $35(8.2)$ & $32(7.5)$ & 84.3 \\
\hline Breastfeeding & $329(76.9)$ & $60(14.0)$ & $39(9.1)$ & 76.9 \\
\hline Mosquito bite & $296(69.2)$ & $96(22.4)$ & $36(8.4)$ & 22.4 \\
\hline Gay sex & $364(85.0)$ & $32(7.5)$ & $35(7.5)$ & 85.0 \\
\hline Oral sex & $297(69.4)$ & $86(20.1)$ & $45(10.5)$ & 69.4 \\
\hline \multicolumn{5}{|l|}{ Knowledge about AIDS prevention } \\
\hline Having sex without using condoms & $327(76.4)$ & $64(15.0)$ & $37(8.6)$ & 76.4 \\
\hline Is AIDS preventable & $403(94.2)$ & $9(2.1)$ & $16(3.7)$ & 94.2 \\
\hline $\begin{array}{l}\text { Can AIDS be prevented by obeying the } \\
\text { sexual morality }\end{array}$ & $384(89.7)$ & $24(5.6)$ & $20(4.7)$ & 89.7 \\
\hline $\begin{array}{l}\text { Women with AIDS should not get } \\
\text { pregnant }\end{array}$ & $264(85.0)$ & $37(8.6)$ & $387(6.3)$ & 85.0 \\
\hline $\begin{array}{l}\text { Must blood for transfusion use be tested } \\
\text { for AIDS virus? }\end{array}$ & $415(97.0)$ & $4(0.9)$ & $12(2.1)$ & 97.0 \\
\hline
\end{tabular}


Table 3: Association between knowledge scores and sociodemographic characteristics among participants $(n=428)$

\begin{tabular}{|c|c|c|c|c|c|}
\hline Characteristic & n & $\bar{x} \pm s$ & $t$ & $F$ & $p$ \\
\hline \multicolumn{6}{|l|}{ Marital status } \\
\hline Married & 127 & $18.630 \pm 4.756$ & -2.976 & & 0.003 \\
\hline $\begin{array}{c}\text { Unmarried } \\
\text { Age }\end{array}$ & 301 & $20.037 \pm 3.694$ & & & \\
\hline$<30$ years & 324 & $19.948 \pm 3.847$ & 2.963 & 0.003 & \\
\hline$\geq 31$ years & 104 & $18.596 \pm 4.618$ & & & \\
\hline \multicolumn{6}{|l|}{ Levels of education } \\
\hline Primary school ${ }^{3,4}$ & 17 & $17.706 \pm 5.807$ & & 13.416 & 0.000 \\
\hline Junior high school ${ }^{3,4}$ & 203 & $18.562 \pm 4.260$ & & & \\
\hline Senior high school ${ }^{1,2}$ & 164 & $20.598 \pm 3.580$ & & & \\
\hline College $\mathrm{e}^{1,2}$ & 44 & $21.591 \pm 2.202$ & & & \\
\hline \multicolumn{6}{|l|}{ Monthly income } \\
\hline$<1000$ Yuan & 165 & $19.528 \pm 4.291$ & & 0.873 & 0.418 \\
\hline 1000 3000 Yuan & 242 & $19.582 \pm 3.930$ & & & \\
\hline > 3000 Yuan & 21 & $20.762 \pm 4.182$ & & & \\
\hline
\end{tabular}

${ }^{1}$ Comparing with the primary school group, $p<0.05 ;{ }^{2}$ comparing with the junior high school group, $p<0.05 ;{ }^{3}$ comparing with the senior high school group, $p<0.05$; ${ }^{4}$ comparing with the college group, $p<0.05$.

Table 4: Attitude about HIV/AIDS among 428 participants

\begin{tabular}{|c|c|c|c|c|}
\hline Attitude & $\begin{array}{c}\text { Yes/approval } \\
(\%)\end{array}$ & $\begin{array}{c}\text { No/disapproval } \\
(\%)\end{array}$ & $\begin{array}{l}\text { I do not } \\
\text { care }(\%)\end{array}$ & $\begin{array}{l}\text { Positive } \\
\text { rate }(\%)\end{array}$ \\
\hline $\begin{array}{l}\text { Is it necessary to use condoms } \\
\text { for sexual intercourse except } \\
\text { contraception? }\end{array}$ & $357(83.4)$ & $38(8.9)$ & $33(7.7)$ & 83.4 \\
\hline $\begin{array}{l}\text { Attitude towards premarital sexual } \\
\text { behaviour }\end{array}$ & $106(24.8)$ & $229(53.5)$ & $93(21.7)$ & 53.5 \\
\hline $\begin{array}{l}\text { What is your attitude towards } \\
\text { prostitution? }\end{array}$ & $12(2.8)$ & $394(92.1)$ & $22(5.1)$ & 92.1 \\
\hline $\begin{array}{l}\text { What is your attitude towards } \\
\text { multiple sexual partners? }\end{array}$ & $12(2.8)$ & $373(87.1)$ & $43(10.0)$ & 87.1 \\
\hline $\begin{array}{l}\text { Are persons with AIDS through } \\
\text { intravenous drug use worthy of } \\
\text { sympathy? }\end{array}$ & $96(22.4)$ & $317(74.1)$ & $15(3.5)$ & 22.4 \\
\hline $\begin{array}{l}\text { Are persons with AIDS through blood } \\
\text { transfusion worthy of sympathy? }\end{array}$ & $381(89.0)$ & $37(8.6)$ & $10(2.3)$ & 89.0 \\
\hline AIDS patients should be separated & $417(97.4)$ & $10(2.4)$ & $1(0.2)$ & 2.4 \\
\hline $\begin{array}{l}\text { Will you go to hospital for an } \\
\text { examination? }\end{array}$ & $415(97.0)$ & $5(1.2)$ & $8(1.9)$ & 97.0 \\
\hline $\begin{array}{l}\text { Do you want to acquire knowledge } \\
\text { about AIDS or other veneral diseases? }\end{array}$ & 389 (90.9) & $22(5.1)$ & $17(4.0)$ & 90.9 \\
\hline $\begin{array}{l}\text { It is necessary to provide AIDS } \\
\text { prevention education to the public }\end{array}$ & $421(98.4)$ & $2(0.5)$ & $5(1.1)$ & 98.4 \\
\hline
\end{tabular}

tudes toward HIV/AIDS among the participants are presented in Table 4.
There were no significant differences in the total scores of attitudes among respondents of different marital status, age, education, and monthly income (Table 5). 
Table 5: Association between attitude scores and sociodemographic characteristics among participants $(n=428)$

\begin{tabular}{|c|c|c|c|c|c|}
\hline \multirow[b]{2}{*}{ Characteristic } & \multicolumn{2}{|c|}{ Attitude score } & \multirow[b]{2}{*}{$\mathbf{Z}$} & \multirow[b]{2}{*}{$\chi^{2}$} & \multirow[b]{2}{*}{$p$} \\
\hline & $\mathbf{n}$ & $\begin{array}{l}\text { Mean } \\
\text { Rank }\end{array}$ & & & \\
\hline \multicolumn{6}{|l|}{ Marital status } \\
\hline Married & 127 & 226 & -1.3 & & 0.206 \\
\hline $\begin{array}{c}\text { Unmarried } \\
\text { Age }\end{array}$ & 301 & 210 & & & \\
\hline$<30$ years & 324 & 207 & -2.1 & & 0.039 \\
\hline$\geq 31$ years & 104 & 235 & & & \\
\hline \multicolumn{6}{|l|}{ Levels of education } \\
\hline Primary school & 17 & 234 & & 3.4 & 0.335 \\
\hline Junior high school & 203 & 208 & & & \\
\hline Senior high school & 164 & 225 & & & \\
\hline College & 44 & 197 & & & \\
\hline \multicolumn{6}{|l|}{ Monthly income } \\
\hline$<1000$ Yuan & 165 & 223 & & 2.3 & 0.313 \\
\hline 1000 3000 Yuan & 242 & 207 & & & \\
\hline > 3000 Yuan & 21 & 233 & & & \\
\hline
\end{tabular}

\section{Sexual history and behaviour}

Over half of the participants (52.6\%) with a mean age of 31.5 (SD 10.3) years had sexual experiences. Of these, 56.4\% (127/225) had sex with their husband, 32.9\% (74/225) had sex with one boyfriend, $10.7 \%(24 / 225)$ had sex with more than one man. The rate of premarital sexual intercourse was $29.9 \%(87 / 291)$. Of currently married respondents, $6.3 \%$ (8/127) reported that they had a non-spousal sexual relationship. Nearly half of the participants (47.4\%) with a mean age of 20.5 years old (SD, 4.0 years), said that they never had any sexual experiences. Among the respondents who had sexual experiences, $57.7 \%(130 / 225)$ reported that they never or only some of the times used condom. Beyond this, 13 par- ticipants of those having sex with more than one man reported that they never used condom or just used it occasionally.

The young, unmarried women had a significantly higher proportion of condom use than those above 30 years old, and/or married ones. No significant differences of condom use were found among groups with different levels of education. However, the respondents having college attainment reported a higher proportion of condom use than those who had primary school attainment. Higher income participants had a higher proportion of condom use than those who were low income, though the difference was not significant $(p=0.070)$. The proportion of condom use among respondents varied by demographic characteristics (Table 6).

\section{DISCUSSION}

We selected migrant females who worked in the restaurant industry and checked their physical health during March 2011. So, the sample appeared representative of the migrant women in the restaurant industry in Guangzhou City. The migrant women were young and most of them were unmarried. Over 50\% had received no higher than junior high school education. The demographic characteristics of the participants were similar to general demographic characteristics in China from the working paper published by the International Labour Organization in 2008 (16).

It is encouraging to note that $91.6 \%$ of respondents had heard of AIDS in our survey, a higher percentage than that reported several years ago in China which was then only $85.4 \%$ (10). Meanwhile, it demonstrated that television and magazine/newspaper constituted the most important modes of dissemination of information about HIV/AIDS to the migrant women, which was in line with the study conducted previously in other cities in China (11).

Table 6: Demographic characteristics and condom use among the participants having sex experiences $(n=225)$

\begin{tabular}{|c|c|c|c|c|c|c|}
\hline \multirow[b]{2}{*}{ Characteristic } & \multicolumn{4}{|c|}{ Condom Use } & \multirow[b]{2}{*}{$\chi^{2}$} & \multirow[b]{2}{*}{$p$} \\
\hline & Always & $\begin{array}{l}\text { Most of } \\
\text { the time }\end{array}$ & $\begin{array}{l}\text { Some of } \\
\text { the time }\end{array}$ & Never & & \\
\hline \multicolumn{7}{|l|}{ Marital status } \\
\hline Married & 17 & 25 & 42 & 43 & \multirow{2}{*}{18.398} & \multirow{2}{*}{0.000} \\
\hline $\begin{array}{c}\text { Unmarried } \\
\text { Age }\end{array}$ & 32 & 21 & 31 & 14 & & \\
\hline$<30$ years & 35 & 27 & 41 & 23 & \multirow[t]{2}{*}{10.535} & \multirow[t]{2}{*}{0.015} \\
\hline$\geq 30$ years & 14 & 19 & 32 & 34 & & \\
\hline \multicolumn{7}{|l|}{ Levels of education } \\
\hline Primary school & 1 & 4 & 3 & 6 & \multirow[t]{4}{*}{8.912} & \multirow[t]{3}{*}{0.445} \\
\hline Middle school & 23 & 23 & 39 & 31 & & \\
\hline High school & 18 & 14 & 24 & 18 & & \\
\hline College and above & 7 & 5 & 7 & 2 & & \\
\hline \multicolumn{7}{|l|}{ Monthly income } \\
\hline$<1000$ Yuan & 15 & 13 & 22 & 26 & \multirow[t]{3}{*}{11.645} & \multirow[t]{3}{*}{0.070} \\
\hline 1000-3000 Yuan & 30 & 26 & 48 & 30 & & \\
\hline > 3000 Yuan & 4 & 7 & 3 & 1 & & \\
\hline
\end{tabular}


Regarding knowledge of HIV/AIDS, studies about female factory workers and sex-workers performed previously showed that the knowledge of HIV/AIDS among respondents was not enough, the awareness rate on HIV/AIDS knowledge was only between $45.9 \%$ and $60.8 \%(11-13)$. Though it was better than previous surveys, only $49.3 \%$ of the participants in our survey had a good level of knowledge. Consistent with the reports on female factory workers and sex-workers (10-15), most people in our survey were aware of the main route of HIV/AIDS transmission and were familiar with precautions needed to take to prevent transmission of HIV. However, some inconsistency in knowledge still existed in some areas, such as that AIDS can be cured, one could be infected with HIV through mosquito bite and daily social encounters. Furthermore, people with higher education had a better knowledge score, which may be explained by the fact that women with higher educational levels may have more chances to obtain the information pertaining to the disease than those in the lower educational level. In addition, married, older women ( $>31$ years) had poorer knowledge, which may be due to the fact that this group did not have enough time or opportunity to acquire HIV/AIDS information.

As to the attitude toward HIV/AIDS, similar to previous studies (10-12), 88.8\% of respondents had relatively positive attitudes towards HIV/AIDS. The majority of the respondents were sympathetic towards AIDS patients, Nevertheless, $80 \%$ of respondents answered that they would be fearful when they made contact with AIDS patients, similar to the situation reported by Zhang et al (15) that nearly twothirds $(61.6 \%)$ of the general workers were not willing to work with an HIV-infected individual. Furthermore, only a small proportion $(2.4 \%)$ of women was against isolating AIDS patients from society, which was much lower than that of sex-workers [50\%] (12). It is noteworthy that, divergent from previous studies $(10-12)$, there were no significant differences in the total scores of attitudes among respondents with different educational levels; it could be that good knowledge about disease may influence attitude, but this does not necessarily translate into positive attitude.

Thus it can be seen that health education has been effective in increasing people' knowledge of HIV/AIDs in China. However, there is still room for improvement of knowledge and attitudes related to HIV/AIDS, such as the transmission route of HIV/AIDS, attitude toward HIVinfected individual or AIDS patients.

In recent years, Chinese people have become more open in relation to sexual relations. However, this change has resulted in early sexual initiation, multiple sex partners and transactional sex, particularly in those who have lower educational attainment $(17,18)$. In this study, among the respondents ever having sexual experience, around $10 \%$ had multiple sex partners. This proportion was similar to that of the migrant women who worked in public places of entertainment (19). However, the proportion was far lower than that among female undergraduate students; when the survey was conducted in China between 2005 and 2006, $29.32 \%$ of respondents reported having multiple sexual partners (20). Premarital sexual practice and sexual activities outside marriage among the respondents were not higher than that in the general population of the same age (21). These indicated that the migrant female workers held a relatively less permissive attitude on sexual relationship. However, con-dom use rate was low in this population; about a quarter of the participants $(23.6 \%)$ was ignorant of the necessity of condom use. Among the respondents who had sexual experiences, $57.7 \%$ reported that they never or only some of the time used condom, which was similar with the common labourer $(57.0 \%)$ but much higher than the sex-workers [29.9\%] (16). Meanwhile, the married respondents were less likely to report condom use than unmarried women who had sexual experience, which was consistent with other reports observed among Chinese migrants $(19,22)$. In addition, the results showed that older age was linked to less condom use. This may suggest that the aim of condom use among a large proportion of the female workers was for contraception rather than preventing HIV infection.

Presently, although many HIV/AIDS educational activities have been promoted in China, attention paid to the migrant population is still insufficient. This survey has revealed insufficient HIV/AIDS related knowledge in the migrant female population in a modern metropolis. The contents of HIV/AIDS education for migrant women should contain knowledge related to reproductive health, sex, empathy and social morals, in addition to the mode of HIV transmission and preventive methods.

Nevertheless, the migrant female workers in China have a great variety of demographic characteristics, working environments and living conditions, thus the conclusions of this study cannot be generalized to the general migrant female population. More investigations are warranted.

\section{CONCLUSIONS}

This survey revealed that a half of respondents only had moderate and low levels of awareness about HIV/AIDS knowledge, although most of them had a positive attitude toward HIV/AIDS. In addition, a relatively lower rate of condom use was reported. The results of the study suggest that there exists room for improvement of knowledge and behaviours related to HIV/AIDS for migrant women in China.

\section{ACKNOWLEDGMENTS}

This work was supported by Major Science and Technology projects in Guangzhou (grant number 2006Z1-E0091) and Guangdong Province 211 Project.

\section{REFERENCES}

1. World Health Organization. Global summary of the epidemic [Internet]. 2010. Available from: http://www.who.int/hiv/data/2011_epi_core_ en.png 
2. Gill B, Huang Y, Lu X. Demography of HIV/AIDS in China. A report of the Task Force on HIV/AIDS Centre for Strategic and International Studies. Washington, DC: Centre for Strategic and International Studies; 2007.

3. Hong Y, Stanton B, Li X, Yang H, Lin D, Fang X et al. Rural-to-urban migrants and the HIV epidemic in China. AIDS Behav 2006; 10: 421-30.

4. Jolly S, Reeves H. Gender and migration: Brighton, UK: BRIGE, Institute of Development Studies; 2005.

5. Meng X, Wang L, Chan S, Reilly KH, Peng Z, Guo W et al. Estimation and projection of the HIV epidemic trend among the migrant population in China. Biomed Environ Sci 2011; 24: 343-8.

6. National Bureau of Statistics of China. Communiqué of the National Bureau of Statistics of People's Republic of China on Major Figures of the 2010 Population Census [1] (No. 2) [Internet]. 2011. Available from: http://www.stats.gov.cn/english/newsandcomingevents/t20110429_402 722516.htm

7. Hong Y, Li X. HIV/AIDS behavioural interventions in China: a literature review and recommendation for future research. AIDS Behav 2009; 13: $603-13$.

8. Zhang K, Ma S. Epidemiology of HIV in China: intravenous drug users, sex workers, and large mobile populations are high risk groups. BMJ 2002; 324: 803-4.

9. The Joint United Nations Programme on HIV and AIDS (UNAIDS). China epidemic and response [Internet]. 2012. Available from: http:// www.unaids.org.cn/en/index/page.asp/ 2012.1.12

10. Fu S, Shen S, Lin A. Survey of knowledge, attitude and risky behaviour related to HIV/AIDS among migrant women workers in Guangzhou. Sofe Science of Health 2009; 23: 309-12. Chinese.

11. Li J, Hu X, Luo D, Xu L, Chen X, Li X et al. The survey of HIV/AIDS related knowledge, attitude and behaviour among migrant peasant workers in middle city in China. West Indian Med J 2010; 59: 418-23.

12. Cai Y, Shi R, Shen T, Pei B, Jiang X, Ye X et al. A study of HIV/AIDS related knowledge, attitude and behaviours among female sex-workers in Shanghai China. BMC Public Health 2010; 10: 377.
13. Ding Z, Meng X, Guo W, Wang L, Ding G, Meng X et al. Awareness of HIV/AIDS related knowledge and HIV infection among migrant women in some areas of Jilin Province in 2008. Prev Med Trib 2010; 16: 1-3. Chinese.

14. Lin A, Gao L, Liang C, Wang Z. A survey of knowledge, attitude and behaviour for AIDS among mobile female worker in Guangzhou. Chinese Journal of Hospital Statistics 2004; 11: 301-04. Chinese.

15. Zhang T, Zhang J, Gao M, He N, Detels R. Knowledge, attitudes and practices of voluntary HIV counselling and testing among rural migrants in central China: a cross-sectional study. Eur J Public Health 2012; 22: 192-7. Epub 2011 Feb 13.

16. Li S (School of Economics and Business, Beijing Normal University). Rural migrant workers in China: scenario, challenges and public policy. (Working paper: no.89). Contract No. 9789221213840; 9789221213857. Geneva: International Labour Office, Policy Integration and Statistics Department; 2008.

17. He N. Sociodemographic characteristics, sexual behaviour, and HIV risks of rural-to-urban migrants in China. BioScience Trends 2007; 1: 72-80. Chinese.

18. Li S, Huang H, Cai Y, Xu G, Huang F, Shen X. Characteristics and determinants of sexual behaviour among adolescents of migrant workers in Shangai (China). BMC Public Health 2009; 9: 195.

19. Mantell JE, Kelvin EA, Sun X, Zhou J, Exner TM, Hoffman S et al. HIV/STI risk by migrant status among workers in an urban high-end entertainment centre in Eastern China. Health Educ Res 2011; 26: 283-95.

20. Yan H, Chen W, Wu H, Bi Y, Zhang M, Li S et al. Multiple sex partner behaviour in female undergraduate students in China: a multi-campus survey. BMC Public Health 2009; 9: 305.

21. Parish WL, Paumann EO, Mojola SA. Sexual behaviour in China: trends and comparisons. Popul Dev Rev 2007; 33: 729-56.

22. Zhou JF, Mantell JE, Ru XM. Reproductive and sexual health of Chinese migrants. Reprod Contracept 2009; 20: 169-82. 